\title{
Root inoculation with Azotobacter chroococcum 76A enhances tomato plants adaptation to salt stress under low $\mathrm{N}$ conditions
}

\author{
Michael James Van Oosten, Emilio Di Stasio, Valerio Cirillo, Silvia Silletti, Valeria Ventorino, Olimpia Pepe, \\ Giampaolo Raimondi and Albino Maggio*
}

\begin{abstract}
Background: The emerging roles of rhizobacteria in improving plant nutrition and stress protection have great potential for sustainable use in saline soils. We evaluated the function of the salt-tolerant strain Azotobacter chroococcum 76A as stress protectant in an important horticultural crop, tomato. Specifically we hypothesized that treatment of tomato plants with A. chroococcum 76A could improve plant performance under salinity stress and sub-optimal nutrient regimen.

Results: Inoculation of Micro Tom tomato plants with A. chroococcum 76A increased numerous growth parameters and also conferred protective effects under both moderate $(50 \mathrm{mM} \mathrm{NaCl})$ and severe $(100 \mathrm{mM} \mathrm{NaCl})$ salt stresses. These benefits were mostly observed under reduced nutrient regimen and were less appreciable in optimal nitrogen conditions. Therefore, the efficiency of $A$. chroococcum 76A was found to be dependent on the nutrient status of the rhizosphere. The expression profiles of LEA genes indicated that A. chroococcum 76A treated plants were more responsive to stress stimuli when compared to untreated controls. However, transcript levels of key nitrogen assimilation genes revealed that the optimal nitrogen regimen, in combination with the strain $A$. chroococcum 76A, may have saturated plant's ability to assimilate nitrogen.

Conclusions: Roots inoculation with A. chroococcum 76A tomato promoted tomato plant growth, stress tolerance and nutrient assimilation efficiency under moderate and severe salinity. Inoculation with beneficial bacteria such as A. chroococcum 76A may be an ideal solution for low-input systems, where environmental constraints and limited chemical fertilization may affect the potential yield.
\end{abstract}

Keywords: Salinity, Micro tom, Tomato, Plant nutrition, Azotobacter chroococcum, Rhizobacteria

\section{Background}

Salinity affects more than $20 \%$ of global agricultural production and it is predicted to increase in its extent and severity in the coming decades [17]. Salinization occurs through both natural and anthropogenic processes [12]. Predictions based on unprecedented variations in rainfall and temperatures indicate that many sources of freshwater for irrigation are at severe risk for salinization [20]. It has been estimated that salinization renders 3 ha

\footnotetext{
* Correspondence: almaggio@unina.it

Department of Agricultural Sciences, University of Naples Federico II, Via Università, 100 Portici, Italy
}

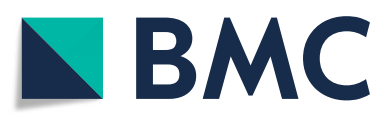

(c) The Author(s). 2018 Open Access This article is distributed under the terms of the Creative Commons Attribution 4.0 International License (http://creativecommons.org/licenses/by/4.0/), which permits unrestricted use, distribution, and reproduction in any medium, provided you give appropriate credit to the original author(s) and the source, provide a link to the Creative Commons license, and indicate if changes were made. The Creative Commons Public Domain Dedication waiver (http://creativecommons.org/publicdomain/zero/1.0/) applies to the data made available in this article, unless otherwise stated. of arable land unproductive every minute [39]. Salinity has major impacts on food production and represents a growing challenge for developing sustainable agricultural systems $[43,57]$.

High concentrations of salt cause both ionic and osmotic stresses. Salinity induces osmotic stress by lowering the soil water potential, thus increasing the energy required for uptake of water and nutrients. Ionic stress is caused by the progressive accumulation of sodium and chloride ions in sensitive plant tissues $[11,16,35]$. Plants employ numerous strategies to survive and adapt to salt stress including control of sodium transport across the plasma and tonoplast 
membranes, osmotic adjustment, upregulation of ROS scavengers and ion compartmentalization in the vacuole [30,34]. The ability to modulate cellular processes under salinity stress requires perception of stress, signal transduction and adaptation to maintain ionic homeostasis $[3,21]$.

Microorganisms living in the rhizosphere often establish mutualistic relationships with living plants [25]. Rhizobacteria improve plant nutrition and in some cases enhance tolerance to drought and salinity [28, 53]). The role of microorganisms and microorganism-based biostimulants to increase tolerance to abiotic stress has been extensively reviewed [53]. One bacterial species candidate for enhancing abiotic stress tolerance is Azotobacter chroococcum. Azotobacter is a free-living aerobic rhizobacteria classified as a plant growth-promoting rhizobacteria (PGPR) $[54,55]$. Capable of fixing nitrogen, it can stimulate plant growth through nutrient supplementation or through the production of phytohormones such as auxins, gibberellins, and cytokinins (Joseph et al., 2007; [23, 1]). Root growth can be stimulated through rhizobacteria expressing the ACC deaminase, which in turn lowers endogenous ethylene synthesis in roots [45]. Screening of various salt-tolerant strains of Azotobacter has revealed that some strains are able to colonize the rhizosphere successfully and promote plant growth in saline soils. One strain in particular, Azotobacter strain ST24, was found to enhance growth when applied in conjunction with salt-tolerant wheat varieties [7]. Inoculation of maize plants with Azotobacter has been reported to improve growth in control and saline stress conditions [42]. Two salt tolerant strains were also reported to alleviate saline stress by improving sodium exclusion and potassium uptake [42]. Experiments with wheat and inoculation with $A$. chroococcum demonstrated improved phosphorous nutrition, increases in grain yield and root biomass, increased osmotic adjustment and activation ROS response genes [27, 46]. A. chroococcum treatments were found to be beneficial to wheat plants under water deficit conditions by increasing total chlorophyll content and relative water content [24]. While most work on the role of Azotobacter has been done on cereal crops, evidence for a growth promotion in tomato (F1 Hybrid, GS -15) has only recently been demonstrated [38]. However, the role of Azotobacter as stress protectant in tomato has yet to be addressed.

Here we report the findings from a greenhouse experiment using the rhizobacteria Azotobacter chroococcum $76 \mathrm{~A}$, which was isolated from compost derived from industrial agricultural wastes from olive pomace, industrial sludge from vegetable processing, and borland from the distillation of molasses [40]. The 76A strain has demonstrated tolerance to salt and drought stresses [54]. Using inoculated plants and uninoculated controls, we performed a series of experiments with two levels of salinity stresses (moderate at $50 \mathrm{mM} \mathrm{NaCl}$ and severe at $100 \mathrm{mM}$
$\mathrm{NaCl}$ ) and nutrient regimens, an optimal nutrient regimen and sub-optimal applied at $50 \%$ of the optimal concentration and without $\mathrm{NH} \mathrm{NO}_{3}$ ). We found that inoculation of Micro Tom tomato plants with the strain A. chroococcum $76 \mathrm{~A}$ facilitated growth and conferred protective effects under both moderate $(50 \mathrm{mM} \mathrm{NaCl})$ and severe $(100 \mathrm{mM}$ $\mathrm{NaCl})$ salt stress at sub-optimal nutritional levels.

\section{Methods \\ Plant growth conditions}

A greenhouse experiment was carried at the experimental station of the University of Naples Federico II, Southern Italy (lat. $43^{\circ} 31^{\prime} \mathrm{N}$, long. $14^{\circ} 58^{\prime} \mathrm{E}$; alt. $60 \mathrm{~m}$ above sea level) with Micro Tom tomato plants. Tomato seeds were germinated in peat on May 2015 and grown until the 3rd-4th true leaf. Plants were transplanted in $10 \mathrm{~cm} \varnothing$ plastic pots at 30 Days-After-Sowing (DAS) containing pure peat moss (100\%) and drip irrigated with nutrient solutions from 35 DAS. At transplanting, the growth substrate was inoculated with Azotobacter chrococcum 76A strain as described in section "Bacterial strain and inoculum preparation". The irrigation water was characterized by a high bicarbonate concentration, presence of $\mathrm{Na}^{+}$and $\mathrm{Cl}^{-}\left(8.63 \mathrm{mg} \mathrm{l}^{-1} \mathrm{Na}^{+}\right.$ and $10.3 \mathrm{mg} \mathrm{l}^{-1} \mathrm{Cl}^{-}$) and with values of $\mathrm{pH}$ and electrical conductivity (EC) of 7.3 and $0.58 \mathrm{dS} \mathrm{m} \mathrm{m}^{-1}$, respectively. Plants were fertigated daily using six nutrient compositions, calculated from a standard nutrient solution (SNS) previously used for Micro Tom [29, 44]. The SNS composition was $1.93 \mathrm{mM} \mathrm{NO}_{3}, 2.53 \mathrm{mM} \mathrm{P}_{2} \mathrm{O}_{5}, 7.64 \mathrm{mM} \mathrm{K} \mathrm{O}_{2} \mathrm{O}$, $1.48 \mathrm{mM} \mathrm{MgO}$, 0.84 $\mu \mathrm{M}$ CuEDTA, $10 \mu \mathrm{M}$ Fe DTPA, $3.45 \mu \mathrm{M}$ Mn EDTA, $2.08 \mu \mathrm{M}$ Mo, $0.83 \mu \mathrm{M}$ Zn EDTA.

The SNS was distributed at two different concentrations, optimal (Opt - 100\% SNS augmented with $3.25 \mathrm{mM}$ $\mathrm{NH} \mathrm{NO}_{3}$ ) and sub-optimal (Sub - 50\% of SNS without $\mathrm{NH} \mathrm{NO}_{3}$ ). Opt and Sub solutions were salinized by adding $\mathrm{NaCl}$ at concentrations of 50 or $100 \mathrm{mM}$. Non-salinized controls were provided for both Opt and Sub nutrient solutions. Overall, 6 nutrient solutions were compared: Sub-0NaCl, Sub-50 NaCl, Sub- $100 \mathrm{NaCl}$, Opt-0 NaCl, Opt-50 NaCl, Opt-100 NaCl. The six nutrient solutions were pumped from independent $100 \mathrm{~L}$ tanks through a drip-irrigation system, with one emitter per plant $\left(2 \mathrm{l} \mathrm{h}^{-1}\right)$. Two fertilization treatments were applied per day, each of 1-3 min duration. The A. chroococcum inoculum [54] was given at 30 and 71 DAS. Non-inoculated plants were included as controls for all treatments.

\section{Bacterial strain and inoculum preparation}

The strain A. chroococcum 76A, previously selected for its multiple plant growth promotion activities as well as antimicrobial activity and tolerance to salt and drought stress $[2,54]$, was used. For inoculum preparation, the strain was grown in Yeast Mannitol (YM) liquid medium at $28{ }^{\circ} \mathrm{C}$ for $24 \mathrm{~h}$ in a rotary shaker $(150 \mathrm{rpm})$. The 
culture was harvested at the late exponential phase of growth, centrifuged at $3293 \mathrm{x} \mathrm{g}$, and the bacterial cells were suspended in a $5 \%$ sucrose solution at the ratio 1:5 (w:v). The strain was freeze-dried and added to quartz sand to reach a microbial concentration of approximately $1 \times 10^{7} \mathrm{CFU} \mathrm{g}^{-1}$. The inoculum was applied in the central part of the pot in the peat substrate before tomato transplanting. For non-inoculated controls, a 5\% sucrose solution lacking bacterial cells was applied to substrate similar to inoculated treatment. Viable microbial counts were performed immediately after transplanting and at the end of the experiment (90 DAS). Rhizosphere samples $(10 \mathrm{~g})$ were suspended in $90 \mathrm{~mL}$ of quarter strength Ringer's solution (Oxoid, Milan, Italy). After shaking, suitable dilutions (1:10) were performed and used to inoculate nitrogen-free medium LG agar [40] by using the Surface Spread Plate Count Method. The plates were incubated for $48-72 \mathrm{~h}$ at $28^{\circ} \mathrm{C}$.

\section{Biometric and physiological measurements}

At the end of the experiment (90 DAS), plants were separated in leaves, stems, roots and fruits for fresh biomass determination and their tissues were dried in a forced-air oven at $80 \mathrm{C}$ for $72 \mathrm{~h}$ for the dry biomass determination. The final plant height, the number of leaves, fruits, leaf area and number were also recorded. The leaf area was measured with a Li-Cor 3000 area meter (Li-Cor, Lincoln, NE-USA).

After flowering, the following physiological measurements were performed: leaf relative water content (RWC), photosynthetic rate, leaf stomatal conductance, water potential and SPAD index. The RWC was measured on the fully expanded fourth or fifth leaf from the top of the plant. RWC was calculated according to Jones and Turner [22]. The photosynthetic rate $(\mathrm{P})$ and stomatal conductance (gs) were determined with a gas exchange ADS LCA-4 infrared gas analyzer (Analytical Development Company, Hoddesdon, UK). The SPAD index was measured with a SPAD 502-Plus chlorophyll meter (Konica Minolta, New Jersey, USA).

The water potential was measured psychrometrically using a dew-point psychrometer (WP4, Decagon Devices, Pullman, Washington, USA). The osmotic potential $(\Psi \pi)$ was measured on frozen leaf samples and the pressure potential $(\Psi \mathrm{p})$ was estimated as the difference between $\Psi_{\mathrm{w}}$ and $\Psi \pi$, assuming a matric potential equal to zero.

\section{Mineral analysis}

Mineral composition was determined using dried, finely ground (mesh $0.5 \mathrm{~mm}$ ) samples of leaves and roots. Anions and cations were extracted in Milli-Q water (Merck Millipore, Darmstadt, Germany) in a thermostatic bath at $80{ }^{\circ} \mathrm{C}$ for $10 \mathrm{~min}$ (ShakeTemp SW22, Julabo, Seelbach, Germany). After centrifuging at $6000 \mathrm{~g}$ for $10 \mathrm{~min}$, the supernatant was filtered $(0.2 \mu \mathrm{m})$ and analyzed by ion chromatography with suppressed conductivity detection using a Dionex ICS-3000 system (Sunnyvale, CA, USA). Cations analysis was carried out with isocratic method $(20 \mathrm{mM}$; flow rate $1 \mathrm{ml} / \mathrm{min})$ using an IonPac CS12A column with a CG12A guard column and methanesulfonic acid as eluent. Anions analysis was performed with $\mathrm{NaOH}$ gradient $(1 \mathrm{mM}-50 \mathrm{mM}$; flow rate $1.5 \mathrm{ml} / \mathrm{min})$ using an IonPac AS11HC column with an AG11HC guard column.

\section{RNA extraction and $q R T-P C R$}

Leaves of 12-week-old plants (90 DAS, 19 DAST) from all treatments were harvested and immediately frozen in liquid nitrogen and stored at $-80{ }^{\circ} \mathrm{C}$. Leaves from the same treatment were mixed and three replications per bulk were analyzed. $100 \mathrm{mg}$ of fresh leaf tissue per sample was homogenized with liquid nitrogen and extracted with $1 \mathrm{ml}$ of TRIzol (Life Technologies, Carlsbad, CA, USA). First-strand synthesis was performed with a QuantiTect Reverse Transcription Kit (QIAGEN, Valencia, CA, USA) using $1 \mu \mathrm{g}$ of RNA. Real-time qPCR reactions, using $10 \mathrm{ng}$ of cDNA per reaction, two experiments, four replicates per experiment, were carried out on an ABI Instruments 7900HT qPCR detection system (Applied Biosystems, Foster City, CA, USA) using Platinum SYBR Green qPCR SuperMix-UDG with ROX (Life Technologies, Carlsbad, CA, USA). All qRT-PCR primers were determined to be within $3 \%$ efficiency of each other. Relative expression levels were calculated using Actin 2 as an internal standard and the $\Delta \Delta \mathrm{Ct}$ method for relative quantification. The primers used in this study are listed in Additional file 1: Tables S1.

\section{Statistical analysis}

Data were analyzed with a two way ANOVA (Nutrient solution x Inoculum). Least Significant Difference (LSD) multiple range comparison tests were used to determine differences between means $(P \leq 0.05)$. For gene expression analysis, the $\Delta \mathrm{Ct}$ values of each gene of interest and the actin reference gene were analyzed using Student's T-test. Single asterisks denote significant differences according to Student $(P<0.1)$ between untreated controls and inoculated, double asterisks denote $(P<0.05)$ and triple asterisks denote $(P<0.01)$ between untreated controls and inoculated plants.

\section{Results}

\section{Bacterial growth}

The strain A. chroococcum 76A, inoculated at a concentration of approximately $6 \mathrm{Log} C \mathrm{CFU} \mathrm{g^{-1 }}$, was able to grow under all experimental conditions. The diazotrophic strain growth significantly increased at the end of the experiment reaching values of approximately $7 \mathrm{Log} \mathrm{CFU} \mathrm{g}^{-1}$ 
(Table 1). Specifically, the highest microbial concentration (from 7.80 \pm 0.05 to $7.94 \pm 0.08 \mathrm{Log}^{\mathrm{CFU} \mathrm{g}}{ }^{-1}$ ) was recovered in the rhizosphere of tomato plants cultivated under sub-optimal nutrient solution (50\% standard nutrient solution) regardless of the salt stress applied (Table 1 ). This result implied that salt stress $(0,50$ and $100 \mathrm{mM}$ $\mathrm{NaCl}$ ) did not exert negative effects on microbial growth. Interestingly, it was observed that conditions with optimal levels of nitrogen significantly limited microbial growth (Table 1).

\section{Plant growth responses and fruit yield}

Inoculation (I) with A. chroococcum 76A and nutrient solutions $(\mathrm{N})$ had both a remarkable effect on plant growth and fruit yield, with a significant interaction (IxN) for some of the biometric parameters considered (Table 2). Shoot dry weight (SDW), fruit fresh weight (FFW) and fruit number per plant (FN) all increased, compared to untreated control plants, upon microbial inoculation (+ 45\% SDW, + 39\% FFW, $+49 \%$ FN). These parameters were also similarly affected by different nutrient solutions (Table 2). The addition of $\mathrm{NaCl}$ caused a decline in terms of plant growth and yield regardless of the nutritional level. At $50 \mathrm{mM}$ and $100 \mathrm{mM} \mathrm{NaCl}$, the average SDW, FFW and FN reduction vs. non-salinized solutions was $-15 \%$ and $-44 \%$ (for SDW), $-37 \%$ and $64 \%$ (for FFW), $-31 \%$ and $-53 \%$ (for FN), respectively (means of Sub + Opt nutritional regimens). It should be noted that in the absence of $\mathrm{NaCl}$, the fruit number ( 9.3 vs. 8.3) at sub-optimal vs. optimal nutritional levels was similar, whereas SDW and FFW were reduced by $21 \%$ and $25 \%$ respectively in optimal conditions. These results indicate that higher nutrient concentration and additional nitrogen provided as $\mathrm{NH} \mathrm{NO}$ with the optimal nutritional regimen did not further improve the number of fruit per plant and it was indeed inhibitory for shoot and fruit growth. A significant interaction between microbial inoculation (I) and nutrient solutions (N) was found for shoot fresh weight (SFW), root dry weight (RDW) and Fruit Dry Weight (FDW) (Fig. 1). For these parameters, although it was observed an overall proportional decline with salinity under both sub-optimal and optimal nutritional regimen, there were substantial differences between inoculated plants and non-inoculated controls. Specifically, at moderate $(50 \mathrm{mM} \mathrm{NaCl})$ and severe (100 mM NaCl) salinity, A. chroococcum 76A treated plants performed always better than uninoculated plants under sub-optimal nutritional regimen in terms of SFW $(+44 \%$ as average of the two salinity treatments), RDW (+ $45 \%)$ and FDW (+56\%). Higher nutrients concentration and addition of $\mathrm{NH} \mathrm{NO}$ (optimal regimen) did not further improve the overall plant performance and it indeed flattened down the differences between A. chroococcum 76A and uninoculated plants. The optimal nutritional level and most likely the extra nitrogen caused a partial inhibition of Azotobacter growth (Table 1) and, consequently, its effects on some growth parameters (Fig. 1).

\section{Gas exchange analysis, water relations and SPAD}

With respect to leaf water potential and gas exchanges (Table 4), there were no differences between control and A. chroococcum 76A treated plants, whereas salinity reduced photosynthesis under sub-optimal nutritional regimen $(-50 \%$ at $100 \mathrm{mM} \mathrm{NaCl})$. The photosynthetic levels under optimal nutritional regimen were generally lower than those at suboptimal nutrition and they did not differ at varying salinity. RWC and SPAD values were $5 \%$ and $15 \%$ higher in A. chroococcum 76A treated than uninoculated control plants, respectively. These parameters also

Table 1 Enumeration of autochthonous free-living $\mathrm{N}_{2}$-fixing bacteria and Azotobacter chroococcum 76A in the rhizosphere of noninoculated $(C)$ and inoculated $(I)$ tomato plants at the end of cultivation cycle

\begin{tabular}{lll}
\hline Treatment & Free-living $\mathrm{N}_{2}$-fixing bacteria (Log CFU/g) & A. chroococcum 76A (Log CFU/g) \\
\hline (C) Optimal N, $100 \mathrm{mM} \mathrm{NaCl}$ & $6.83 \pm 0.13^{\mathrm{c}}$ & - \\
(C) Optimal N, $50 \mathrm{mM} \mathrm{NaCl}$ & $6.63 \pm 0.30^{c}$ & - \\
(C) Optimal N, $0 \mathrm{mM} \mathrm{NaCl}$ & $6.77 \pm 0.07^{c}$ & - \\
(C) Sub-Optimal N, $100 \mathrm{mM} \mathrm{NaCl}$ & $6.80 \pm 0.18^{\mathrm{c}}$ & - \\
(C) Sub-Optimal N, $50 \mathrm{mM} \mathrm{NaCl}$ & $6.66 \pm 0.31^{c}$ & - \\
(C) Sub-Optimal N, $0 \mathrm{mM} \mathrm{NaCl}$ & $6.74 \pm 0.24^{\mathrm{c}}$ & - \\
(I) Optimal N, $100 \mathrm{mM} \mathrm{NaCl}$ & $6.72 \pm 0.20^{c}$ & $7.67 \pm 0.04^{\mathrm{b}}$ \\
(I) Optimal N, $50 \mathrm{mM} \mathrm{NaCl}$ & $6.67 \pm 0.18^{\mathrm{c}}$ & $7.58 \pm 0.06^{\mathrm{b}}$ \\
(I) Optimal N, $0 \mathrm{mM} \mathrm{NaCl}$ & $6.81 \pm 0.13^{\mathrm{c}}$ & $7.59 \pm 0.09^{\mathrm{b}}$ \\
(I) Sub-Optimal N, $100 \mathrm{mM} \mathrm{NaCl}$ & $6.50 \pm 0.16^{\mathrm{c}}$ & $7.81 \pm 0.05^{\mathrm{a}}$ \\
(I) Sub-Optimal N, $50 \mathrm{mM} \mathrm{NaCl}$ & $6.58 \pm 0.07^{\mathrm{c}}$ & $7.80 \pm 0.05^{\mathrm{a}}$ \\
(I) Sub-Optimal N, $0 \mathrm{mM} \mathrm{NaCl}$ & $6.51 \pm 0.15^{\mathrm{c}}$ & $7.94 \pm 0.08^{\mathrm{a}}$
\end{tabular}

Different letters after the values indicate significant differences (Tukey's HDS post hoc test, $P<0.05$ )

The values represent the means \pm SD of three replicates of three independent experiments 
Table 2 Effect of Azotobacter chroococcum 76A on the main biometric parameters of Micro Tom grown under increasing salinity (0, 50, $100 \mathrm{mM} \mathrm{NaCl}$ ) and two nutrient regimens (Sub - Suboptimal, Opt- Optimal)

\begin{tabular}{|c|c|c|c|c|c|c|c|}
\hline & Shoots FW & Shoots DW & Roots DW & Fruits FW & Fruits number & Fruits DW & Leaves FW \\
\hline & g & g & g & g & & g & g \\
\hline \multicolumn{8}{|l|}{ Inoculum (I) } \\
\hline Control & $15.0 \mathrm{~b}$ & $1.1 \mathrm{~b}$ & $0.1 \mathrm{~b}$ & $9.6 \mathrm{~b}$ & $5.1 \mathrm{~b}$ & $0.9 \mathrm{~b}$ & $0.7 \mathrm{~b}$ \\
\hline $76 \mathrm{~A}$ & 19.7 a & $1.6 \mathrm{a}$ & $0.2 \mathrm{a}$ & $13.3 \mathrm{a}$ & $7.6 \mathrm{a}$ & $1.4 \mathrm{a}$ & $1.0 \mathrm{a}$ \\
\hline \multicolumn{8}{|l|}{ Nutrent Solution (N) } \\
\hline Sub - 0 mM NaCl & $27.7 \mathrm{a}$ & $1.9 \mathrm{a}$ & $0.2 \mathrm{a}$ & 19.8 a & $9.3 \mathrm{a}$ & $1.8 \mathrm{a}$ & $1.1 \mathrm{a}$ \\
\hline $\mathrm{Sub}-50 \mathrm{mM} \mathrm{NaCl}$ & $18.2 \mathrm{~b}$ & $1.7 \mathrm{ab}$ & $0.2 \mathrm{a}$ & $11.3 \mathrm{bc}$ & $6.4 \mathrm{~b}$ & $1.3 \mathrm{~b}$ & $0.9 \mathrm{ab}$ \\
\hline Sub - $100 \mathrm{mM} \mathrm{NaCl}$ & $10.7 c$ & $1.0 \mathrm{C}$ & $0.1 \mathrm{~b}$ & $6.3 d$ & $4.2 \mathrm{c}$ & $0.7 c$ & $0.6 b$ \\
\hline Opt - 0 mM NaCl & $21.4 a b$ & $1.5 \mathrm{~b}$ & $0.2 \mathrm{a}$ & $14.8 \mathrm{~b}$ & $8.3 \mathrm{a}$ & $1.6 \mathrm{ab}$ & $1.0 \mathrm{a}$ \\
\hline Opt - $50 \mathrm{mM} \mathrm{NaCl}$ & $16.6 \mathrm{~b}$ & $1.2 \mathrm{bc}$ & $0.1 \mathrm{~b}$ & $10.5 \mathrm{c}$ & $5.8 \mathrm{~b}$ & $1.0 \mathrm{~b}$ & $0.7 \mathrm{~b}$ \\
\hline Opt - $100 \mathrm{mM} \mathrm{NaCl}$ & $9.4 \mathrm{c}$ & $0.9 c$ & $0.1 \mathrm{c}$ & $6.0 d$ & $4.0 \mathrm{C}$ & $0.6 c$ & $0.5 \mathrm{~b}$ \\
\hline \multicolumn{8}{|l|}{ Significance } \\
\hline । & $* * *$ & $* * *$ & $* * *$ & $* * *$ & $* * *$ & $* * *$ & * \\
\hline$N$ & $* * *$ & $* * *$ & $* * *$ & $* * *$ & $* * *$ & $* * *$ & $* * *$ \\
\hline IXN & * & ns & $*$ & ns & ns & * & ns \\
\hline
\end{tabular}

$\mathrm{ns}, * * * * * * * N$ Non significant or significant at $P \leq 0.05,0.01$, and 0.001 , respectively

decreased with salinity under both suboptimal and optimal nutritional levels. In the absence of $\mathrm{NaCl}$, the $\mathrm{RWC}$ under sub-optimal nutritional level was $7 \%$ higher than under optimal nutritional regimen (compare Sub-Opt $0 \mathrm{mM} \mathrm{NaCl}$ vs. Opt $0 \mathrm{mM} \mathrm{NaCl}$ in Table 4).

\section{Leaf ion contents}

The leaf ion profile was significantly altered in response to both microbial inoculation (I) and nutritional regimen (N) (Table 3). Leaf ammonia concentration was higher under optimal fertilization (3.1 mg/kg dry matter) compared to the sub-optimal regimen $(0.8 \mathrm{mg} / \mathrm{kg}$ dry matter $)$. Potassium decreased with respect to both the microbial treatment $(-15 \%)$ and nutritional regimens with a $36 \%$ and $45 \%$ lower $\mathrm{K}$ tissue concentrations at 50 and $100 \mathrm{mM}$ $\mathrm{NaCl}$, respectively, compared to non-salinized solutions as average of sub-optimal and optimal nutritional regimen, (Table 3). For all other ions, a significant interaction was found between microbial treatment and nutritional regimen (Fig. 2). $\mathrm{Na}^{+}$and $\mathrm{Cl}^{-}$levels in leaves increased upon addition of $\mathrm{NaCl}$ to the nutrient solution under both sub-optimal and optimal nutritional regimens. However, the concentrations of these ions were remarkably higher in A. chroococcum $76 \mathrm{~A}$ treated plants vs. uninoculated controls in the absence of $\mathrm{NaCl}$ stress with $+91 \%$ for $\mathrm{Na}^{+}$, under optimal nutrient regimen (Fig. 2a) and $+56 \%$ and + $76 \%$ for $\mathrm{Cl}^{-}$under sub-optimal and optimal nutritional regimens, respectively (Fig. 2b). $\mathrm{Ca}^{2+}$ was always higher in A. chroococcum $76 \mathrm{~A}$ plants under sub-optimal nutritional levels (Fig. 2c). The differences between inoculated plants and controls were generally attenuated under optimal nutritional regimen, although in the absence of $\mathrm{NaCl}$ the leaf $\mathrm{Ca}^{2+}$ level of inoculated plants was still twice that of uninoculated controls. $\mathrm{Mg}^{2+}$ levels were rather stable in non-inoculated plants under all nutritional regimens, with a moderate decline under optimal nutritional conditions, in the absence of $\mathrm{NaCl}$. 76 A treated plants again performed slightly better under sub-optimal nutritional regimen with highest values at 0 and $50 \mathrm{mM} \mathrm{NaCl}$ compared to all other treatments (Fig. $2 \mathrm{~d}$ ). $\mathrm{NO}_{3}{ }^{-}$levels generally declined with salinization and were lower in $76 \mathrm{~A}$ plants vs. uninoculated controls at 0 and $50 \mathrm{NaCl}(-63 \%$ and $-59 \%$, respectively) (Fig. 2e). This pattern was somehow reverted under optimal fertilization, at least in the absence of $\mathrm{NaCl}$ (+32\% in $76 \mathrm{~A}$ plants). For $\mathrm{PO}_{3}$ ions, we found similar levels in inoculated vs. non-inoculated plants at all nutrient solutions tested, with the exception of significant $47 \%$ and $46 \%$ lower levels at sub-optimal nutritional level + $100 \mathrm{mM} \mathrm{NaCl}$ and at optimal nutritional level in the absence of salt (Fig. 2f).

\section{Gene expression}

Four genes were chosen to correlate the rates of nitrogen content to molecular mechanisms that play a role in nitrogen uptake: the $\mathrm{NH}_{4}{ }^{+}$transporter $(A M T 2)$, the $\mathrm{NO}_{3}$ transporter (NRT2.1), nitrite reductase (Nii), and nitrate reductase $(N R)$ The plasma membrane sodium antiporter, SALT OVERLY SENSITIVE 1 gene (SOS1), two members of the $\mathrm{Na}^{+}-\mathrm{K}^{+} / \mathrm{H}^{+}$antiporter family (NHX1 and $N H X 2)$, and the $\mathrm{Na}^{+}$-selective class I-HKT transporter $(H K T 1 ; 1)$ were used to assess ion transport. Optimal $\mathrm{N}$ levels led to a general decreased expression of 


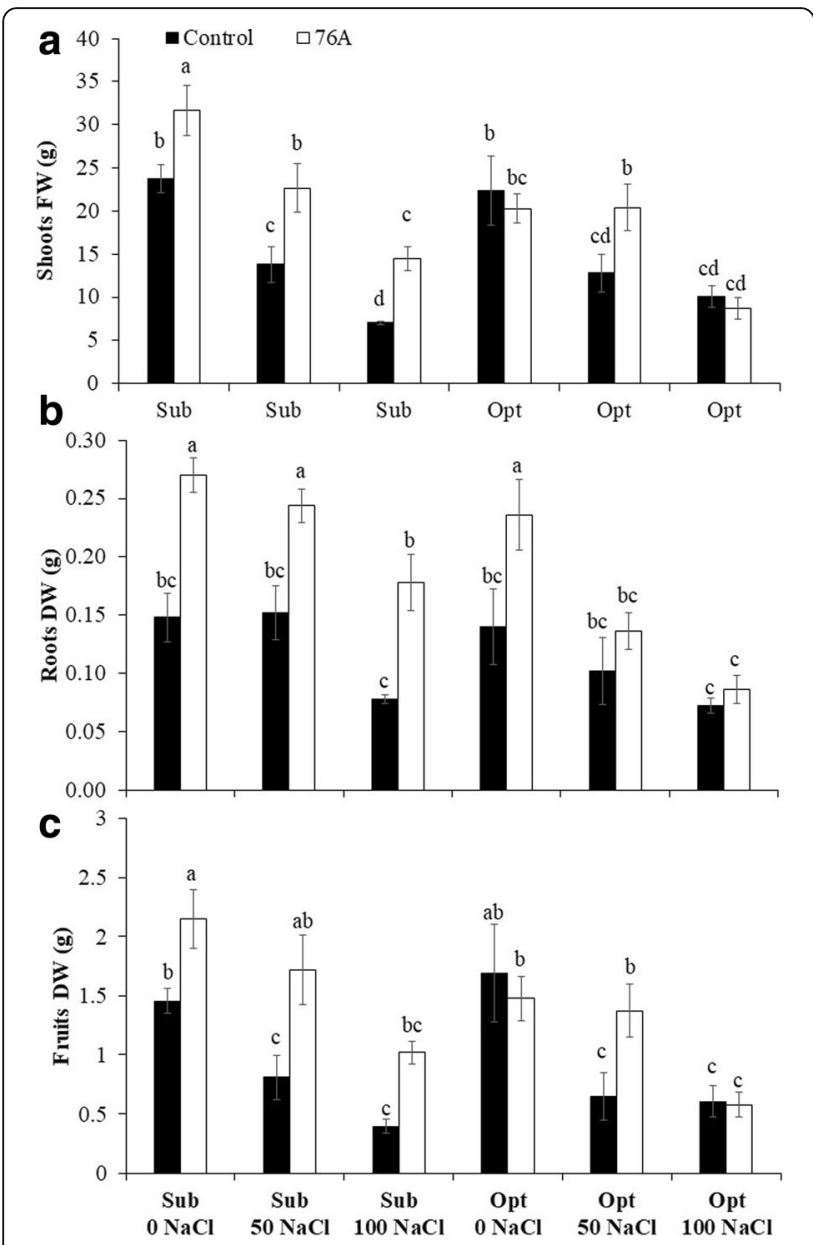

Fig. 1 Effect of Azotobacter chroococcum 76A on biometric parameters of Micro Tom grown under increasing salinity $(0,50$, $100 \mathrm{mM} \mathrm{NaCl}$ ) and two nutrient regimens (Sub - Suboptimal, OptOptimal). a Shoot Fresh Weight, (b) Roots dry weight, (c) Fruits dry weight. Vertical bars indicate \pm SE of means, different letters denote significant differences between uninoculated controls and plants inoculated with A. chroococcum 76A according to Least Significant Different (LSD) multiple range comparison test

$A M T 2, N R T 2.1$ and $N R$ in leaves (Fig. 4). For these genes, inoculation with $A$. chroococcum 76A did not induce notable changes to expression under sub-optimal $\mathrm{N}$, with the exception of NRT2.1 whose relative expression was less than half of the untreated control at moderate and severe salinity (Fig. 4). The LATE EMBRYOGENESIS ABUN$D A N T$ (LEA) gene was chosen for its high inducibility under both salt and drought stress as previously reported [19]. LEA expression in inoculated plants under stress treatment was higher than in uninoculated, implying a level of crosstalk between signaling and nutrition. $L E A$ serves as an indicator of stress response and the increased expression levels seen at optimal $\mathrm{N}$ conditions indicate that additional nitrogen exacerbated the stress phenotype. The expression of the plasma membrane sodium antiporter, SOS1 was also evaluated. SOS1 is the primary transporter responsible for exclusion of sodium ions from the cytoplasm and required for salt tolerance [17]. Expression in sub-optimal conditions was slightly lower in inoculated plants (Fig. 4). Conversely, in the optimal nutrient regimen, expression of SOS1 was higher in inoculated plants. A second sodium transporter, the $\mathrm{Na}^{+}$-selective class I-HKT transporter (HKT1;1), was selected to evaluate the ion homeostasis (Ansins, et al., 2012). HKT1;1 expression was not induced upon inoculation with A. chroococcum 76A or by salt stress in sub-optimal nutrient condition in leaves of MicroTom plants. Expression of $H K T 1 ; 1$ was slightly increased in optimal nutrients and upon Azotobacter inoculation (Additional file 1: Figure S1). Finally, expression of $N H X 1$ and NHX2 showed increases in all salt stress conditions, with no remarkable differences between inoculated and uninoculated plants (Additional file 1: Figure S1).

\section{Discussion}

\section{A. chroococcum 76A is an effective salt stress protectant} Optimizing fertilization techniques to reduce the environmental impact of chemical fertilizers is critical for developing sustainable agricultural systems ([13]; Dadkhah, 2013). Azotobacter based biofertilizers, alone or in combination with other microbial-based products, show promise as alternatives to chemical fertilization, especially in organic production [51]. Data on the effects of rhizobacteria applications on tomato performance are limited [33, 38]. Here we provide evidence for remarkable effects of $A$. chroococcum $76 \mathrm{~A}$ on plant growth and yield at reduced nutritional level (Table 2 and Fig. 1). The strain A. chroococcum 76A has been previously characterized to be tolerant to desiccation and as halotolerant, capable of growing in high salinity medium, at concentrations which would be lethal for other bacterial strains [54]. Furthermore, the 76A strain was shown to form association with tomato roots in vitro. This strain exerted multiple plant growth promotion activities including indole-3-acetic acid and siderophore production, phosphate solubilization, and ACC deaminase activity [54]. Based on these properties, we hypothesized that root inoculation with the halotolerant $76 \mathrm{~A}$ strain may confer benefits in terms of nitrogen availability and salt tolerance in tomato. The presence of moderate and severe salt stress did not inhibit the growth of the 76A strain in the soil while higher $\mathrm{N}$ content had a slight inhibitory effect on growth (Table 1), as previously reported for Azotobacter ([5, 36]). In this study we observed that in tomato, $A$. chroococcum $76 \mathrm{~A}$ acted as a general growth enhancer (Table 2). Similar results in terms of plant growth and yield have been reported by El-Shanshoury et al. [14] for dry weights of shoots and roots, $+84 \%$ and $+200 \%$ respectively in inoculated plants, and in terms of fruit quality [38]. Use of Azotobacter strains in field trials has also indicated that inoculation increases growth, particularly when modest nitrogen supplementation was used [47]. In contrast, our 
Table 3 Effect of Azotobacter chroococcum 76A on the leaves ions of Micro Tom grown under increasing salinity (0, 50, 100 mM $\mathrm{NaCl}$ ) and two nutrient regimens (Sub - Suboptimal, Opt- Optimal)

\begin{tabular}{|c|c|c|c|c|c|c|c|c|}
\hline & $\begin{array}{l}\mathrm{Na} \\
\mathrm{mg} / \mathrm{kg} \text { d.m. }\end{array}$ & $\begin{array}{l}\mathrm{NH}_{4} \\
\mathrm{mg} / \mathrm{kg} \text { d.m. }\end{array}$ & $\begin{array}{l}\mathrm{K} \\
\mathrm{mg} / \mathrm{kg} \text { d.m. }\end{array}$ & $\begin{array}{l}\mathrm{Mg} \\
\mathrm{mg} / \mathrm{kg} \text { d.m. }\end{array}$ & $\begin{array}{l}\mathrm{Ca} \\
\mathrm{mg} / \mathrm{kg} \text { d.m. }\end{array}$ & $\begin{array}{l}\mathrm{Cl} \\
\mathrm{mg} / \mathrm{kg} \text { d.m. }\end{array}$ & $\begin{array}{l}\mathrm{NO}_{3} \\
\mathrm{mg} / \mathrm{kg} \text { d.m. }\end{array}$ & $\begin{array}{l}\mathrm{PO}_{4} \\
\mathrm{mg} / \mathrm{kg} \text { d.m }\end{array}$ \\
\hline \multicolumn{9}{|l|}{ Inoculum (I) } \\
\hline Control & 19.6 & 2.6 & $29.1 \mathrm{a}$ & $3.7 \mathrm{~b}$ & $10.7 \mathrm{~b}$ & $42.5 \mathrm{~b}$ & $14.3 \mathrm{a}$ & $18.6 \mathrm{a}$ \\
\hline $76 \mathrm{~A}$ & 22.2 & 2.3 & $24.7 b$ & $4.1 \mathrm{a}$ & $14.6 \mathrm{a}$ & $57.1 \mathrm{a}$ & $11.2 \mathrm{~b}$ & $13.7 b$ \\
\hline \multicolumn{9}{|l|}{ Nutrient Solution (N) } \\
\hline $\mathrm{Sub}-0 \mathrm{mM} \mathrm{NaCl}$ & $1.8 \mathrm{C}$ & $0.8 \mathrm{c}$ & $42.8 \mathrm{a}$ & $4.7 \mathrm{a}$ & $13.7 \mathrm{a}$ & $25.9 \mathrm{~d}$ & $19.0 \mathrm{a}$ & $16.3 \mathrm{ab}$ \\
\hline Sub - $50 \mathrm{mM} \mathrm{NaCl}$ & $22.8 b$ & $1.2 \mathrm{c}$ & $23.9 c$ & $4.4 \mathrm{a}$ & $14.8 \mathrm{a}$ & $55.6 \mathrm{bc}$ & $10.3 b c$ & $13.8 \mathrm{C}$ \\
\hline Sub - $100 \mathrm{mM} \mathrm{NaCl}$ & $33.0 \mathrm{a}$ & $1.4 \mathrm{c}$ & $21.2 \mathrm{~cd}$ & $4.2 \mathrm{a}$ & $10.3 b$ & $61.6 \mathrm{~b}$ & $7.9 c$ & $15.9 \mathrm{~b}$ \\
\hline Opt - 0 mM NaCl & $7.8 \mathrm{C}$ & $3.1 \mathrm{~b}$ & $30.9 \mathrm{~b}$ & $3.2 \mathrm{~b}$ & $13.4 \mathrm{a}$ & $31.8 d$ & $19.6 \mathrm{a}$ & $18.3 \mathrm{a}$ \\
\hline Opt - $50 \mathrm{mM} \mathrm{NaCl}$ & $24.5 b$ & $3.0 \mathrm{~b}$ & $23.6 c$ & $3.3 \mathrm{~b}$ & $14.9 \mathrm{a}$ & $50.5 \mathrm{C}$ & $11.8 \mathrm{~b}$ & $14.6 \mathrm{bc}$ \\
\hline Opt - $100 \mathrm{mM} \mathrm{NaCl}$ & $35.5 \mathrm{a}$ & $5.2 \mathrm{a}$ & $19.1 \mathrm{~d}$ & $3.5 \mathrm{~b}$ & $9.0 \mathrm{~b}$ & $73.5 \mathrm{a}$ & $7.8 \mathrm{c}$ & $18.2 \mathrm{a}$ \\
\hline \multicolumn{9}{|l|}{ Significance } \\
\hline 1 & ns & ns & $* *$ & $* * *$ & $* * *$ & $* * *$ & $* * *$ & $* * *$ \\
\hline $\mathrm{N}$ & $* * *$ & $* * *$ & $* * *$ & $* * *$ & $* *$ & $* * *$ & $* * *$ & $* *$ \\
\hline IXN & * & ns & ns & $* * *$ & $* *$ & $* * *$ & $* * *$ & $* * *$ \\
\hline
\end{tabular}

$\mathrm{ns}, * * * * * * *$ Non significant or significant at $P \leq 0.05,0.01$, and 0.001 , respectively
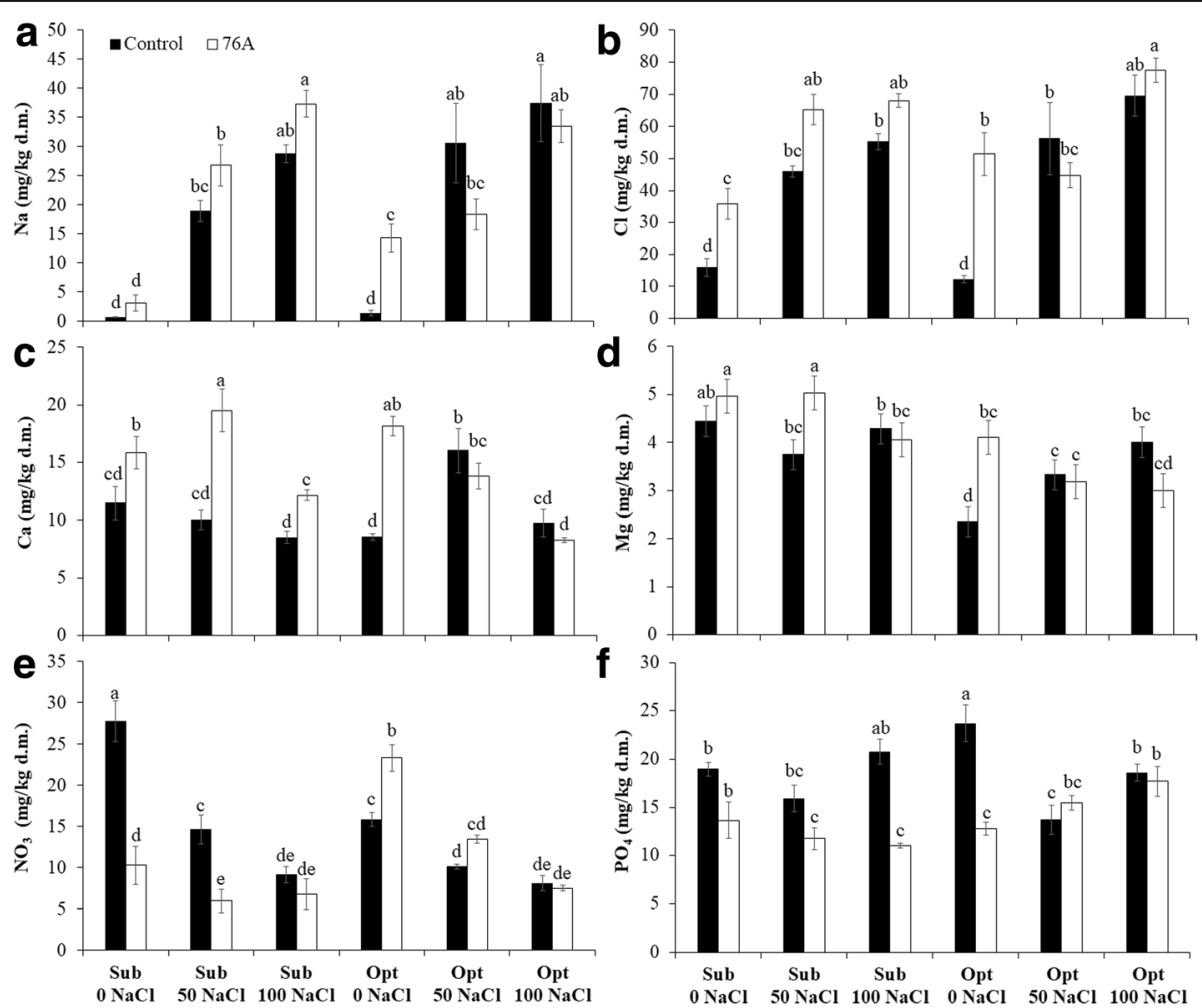

Fig. 2 Effect of Azotobacter chroococcum 76A on the leaves ions content of Micro Tom grown under increasing salinity $(0,50,100 \mathrm{mM} \mathrm{NaCl})$ and two nutrient regimens (Sub - Suboptimal, Opt- Optimal). a Na ${ }^{+}$, (b) $\mathrm{Mg}^{2+}$, (c) $\mathrm{Ca}^{2+}$, (d) $\mathrm{Cl}^{-}$, (e) $\mathrm{NO}_{3}{ }^{-}$, (f) $\mathrm{PO}_{4}{ }^{-}$. Vertical bars indicate $\pm \mathrm{SE}$ of means, different letters denote significant differences between uninoculated controls and plants inoculated with $\mathrm{A}$. chroococcum 76A according to Least Significant Different (LSD) multiple range comparison test 
results demonstrate that plants grown at sub-optimal nutritional conditions and in the presence of $A$. chroococcum $76 \mathrm{~A}$ performed better than any other treatment in term of shoot fresh weight, root dry weight and fruit dry weight (Fig. 1). This indicates the outstanding potential of this strain as potential substitute of chemical fertilization, beyond its current role as a complementary additive. This function seemed to be partially repressed at optimal nutritional levels (Fig. 1), and is likely linked to the inhibitory effect of higher $\mathrm{N}$ concentrations on bacterial growth (Table 1 ). We cannot rule out, however, the possibility that the optimal nutritional regimen used in our study may have resulted in some toxicity level to plants in our experimental conditions. Remarkably, inoculation with the strain $A$. chroococcum $76 \mathrm{~A}$ in our experiments consistently increased yield in terms of fruit fresh weight and number. In contrast, under optimal nutritional conditions, inoculation improved fruits dry weight only at moderate salt stress (Fig. 1). These results further indicate that $A$. chroococcum 76A, in terms of growth and yield promotion, is more suited to sub-optimal nutritional conditions and increased levels of nitrogen present in the optimal nutritional treatment were inhibitory in terms of yield (Fig. 1). The effects of A. chroococcum on plant growth have been associated with the production of auxins, cytokinins, and GA like molecules which all have well established functions in plant growth regulation [55]. In our experimental conditions gas exchange analysis did not reveal differences in A. chroococcum 76A treated vs. control plants. It must be noted that gas exchanges and water relation parameters were generally low at time of measurement (after flowering) when we observed incipient leaf senescence. Nevertheless, inoculated plants had higher Relative Water Content (RWC) suggesting that the microbial activity may have triggered the production and/or uptake of osmolytes that may have contributed to maintain a favorable water uptake (Table 4) with beneficial effects on cellular turgor and photosynthetic system. A further, yet indirect, indication of the protective effects of $A$. chroococcum $76 \mathrm{~A}$ on the photosynthetic machinery was provided by the SPAD results (Table 4). The Single Photoelectric Analyzing Diode (SPAD) meter is used for fast, reliable and non-destructive measurement of leaf chlorophyll levels [31]. All SPAD values measured for unstressed plants were in the range of 40-50, close to other reported values for tomatoes grown under similar conditions $[18,26]$. We observed that $A$. chroococcum 76A treated plants demonstrated higher values than uninoculated controls, suggesting a protective effect of $A$. chroococcum $76 \mathrm{~A}$ treatment on the photosynthetic machinery.

lonic profile reveals a stress pre-adaptation state of $A$. chroococcum 76A treated plants

Tomato plants treated with $A$. chroococcum $76 \mathrm{~A}$ had higher levels of $\mathrm{Na}^{+}$and $\mathrm{Cl}^{-}$ions compared to their relative untreated controls (Table 3). The bacterial inoculum seemed to have a tissue concentration effect on the low levels of $\mathrm{Na}^{+}$and $\mathrm{Cl}^{-}$ions dissolved in non-salinized irrigation water (Table 3; Fig. 2a, b). This increase mirrored the increase of $\mathrm{Ca}^{2+}$ (Fig. 2c) that typically is associated with protection from osmotic and ionic stress [56]. While $\mathrm{Na}^{+}$ions may serve as cheap osmoticum in stress adaptation [30] and may have stimulated root growth (Fig. $1 \mathrm{~b}$ ), $\mathrm{Ca}^{2+}$ is a fundamental component of the regulatory machinery for cellular ion homeostasis during salinity stress but also hormonal regulation and growth control [4]. The increase of cytosolic $\mathrm{Ca}^{2+}$ (which was 30\% higher in $76 \mathrm{~A}$ plants vs. control plants) under salt stress triggers the SOS pathway, through the activation of $\mathrm{Ca}^{2+}$-binding protein SOS3 and the kinase SOS2, which, upon SOS3 activation, form a complex that stimulates activity of the $\mathrm{Na}^{+}$/ $\mathrm{H}^{+}$exchanger SOS1. Activation of SOS1 in turn will remove $\mathrm{Na}^{+}$from the cytoplasm relieving its toxic effects [8]. High apoplastic $\mathrm{Na}^{+}$would serve as osmoticum without impairing cellular functions [17]. Consistent with this mechanism of $\mathrm{Na}^{+}$detoxification, expression of SOS1 increased in all salt stress treatments. However, under sub-optimal nutrient regimen, plants inoculated with 76A had lower levels of SOS1 expression than uninoculated controls (Fig. 4) and accumulated more sodium in salt stress conditions. Lower levels of SOS1 expression have been shown to increase root and shoot accumulation of sodium in tomato [37]. While salt stress reduced the $\mathrm{K}^{+} / \mathrm{Na}^{+}$ratio under both nutritional regimens (Fig. 3), the only notable differences in this ratio between controls and inoculated plants were observed in non-stress conditions. In the absence of stress, plants inoculated with A. chroococcum $76 \mathrm{~A}$ had much lower $\mathrm{K}^{+} / \mathrm{Na}^{+}$ratios than controls. The strain $A$. chroococcum $76 \mathrm{~A}$ appears to affect the $\mathrm{K}^{+} / \mathrm{Na}^{+}$ ratio by increasing the sodium content. However, this effect was not observed when salt stress was imposed. The mechanism responsible for increased $\mathrm{Na}^{+}$and $\mathrm{Cl}^{-}$ is unclear, but it does not appear to inhibit growth in control conditions and interestingly does not come into play under moderate or severe salt stress. A side effect of high leaf $\mathrm{Cl}^{-}$was a reduced $\mathrm{PO}_{4}{ }^{-}$concentration (Fig. 2f), possibly due to competition between these two anions [9, 41]. Consistent with the $\mathrm{PO}_{4}{ }^{-}$pattern, $\mathrm{NO}_{3}{ }^{-}$also decreased in sub-optimal nutritional conditions (Figs. 2e). Low $\mathrm{NO}_{3}{ }^{-}$levels have been associated to high $\mathrm{Na}^{+}$and $\mathrm{Cl}^{-}$ availability/uptake in/from the root zone $[10,49]$. However nitrate increased in response to optimal $\mathrm{N}$ with inoculated plants containing more nitrate than controls in unstressed conditions. A. chroococcum 76A may have likely facilitated assimilation of nitrogen although high salinity was observed to inhibit increased nitrate content. Synergistic effects when nitrogen supplementation is used in combination with Azotobacter strains have been reported [47]. 
Table 4 Effect of Azotobacter chroococcum 76A on the Relative Water Content (RWC), SPAD index, Water Potential, Net Photosynthesis (P), Stomatal Conductence (gs) of Micro Tom grown under increasing salinity $(0,50,100 \mathrm{mM} \mathrm{NaCl})$ and two nutrient regimens (Sub Suboptimal, Opt- Optimal)

\begin{tabular}{|c|c|c|c|c|c|}
\hline & $\begin{array}{l}P \\
\mu \mathrm{mol} \mathrm{m}^{-2} \mathrm{~s}^{-1}\end{array}$ & $\begin{array}{l}\text { gs } \\
\mathrm{mol} \mathrm{m}{ }^{-2} \mathrm{~s}^{-1}\end{array}$ & $\begin{array}{l}\text { Water Potential } \\
\mathrm{MPa}\end{array}$ & $\begin{array}{l}\text { RWC } \\
\%\end{array}$ & SPAD \\
\hline \multicolumn{6}{|l|}{ Inoculum (I) } \\
\hline Control & 1.5 & 0.013 & -2.3 & $67.7 \mathrm{~b}$ & $45.4 \mathrm{~b}$ \\
\hline $76 \mathrm{~A}$ & 1.2 & 0.017 & -2.2 & $71.0 \mathrm{a}$ & 52.3 a \\
\hline \multicolumn{6}{|l|}{ Nutrent Solution (N) } \\
\hline Sub - 0 mM NaCl & $2.0 \mathrm{a}$ & 0.020 & -2.1 & 76.8 a & $51.8 \mathrm{ab}$ \\
\hline Sub - $50 \mathrm{mM} \mathrm{NaCl}$ & $1.8 \mathrm{a}$ & 0.015 & -1.9 & $66.2 c$ & 50.7 b \\
\hline Sub - $100 \mathrm{mM} \mathrm{NaCl}$ & $1.0 \mathrm{~b}$ & 0.013 & -1.8 & $68.7 \mathrm{bc}$ & $45.6 \mathrm{c}$ \\
\hline Opt - 0 mM NaCl & $1.1 \mathrm{~b}$ & 0.018 & -2.5 & $71.3 \mathrm{~b}$ & 54.3 a \\
\hline Opt - 50 mM NaCl & $0.8 \mathrm{~b}$ & 0.010 & -2.6 & $66.1 \mathrm{c}$ & $50.2 \mathrm{~b}$ \\
\hline Opt - $100 \mathrm{mM} \mathrm{NaCl}$ & $1.1 \mathrm{~b}$ & 0.020 & -2.7 & $67.1 \mathrm{c}$ & $40.7 c$ \\
\hline \multicolumn{6}{|l|}{ Significance } \\
\hline । & ns & ns & ns & $* *$ & $* * *$ \\
\hline N & $* *$ & ns & ns & $* * *$ & $* * *$ \\
\hline IXN & ns & ns & ns & ns & ns \\
\hline
\end{tabular}

$\mathrm{ns}, * ; * * * * *$ Non significant or significant at $P \leq 0.05,0.01$, and 0.001 , respectively

Molecular mechanisms underlying ion partitioning and $A$. chroococcum 76A induced stress protection

AMT2 expression was barely detectable under optimal nutritional regimen and moderate salt stress (Fig. 4). Nitrogen transporters such as, NRT2.1 and AMT2 as well as Nii and $N R$ are known to be transcriptionally down regulated by high levels of $\mathrm{N}$ and metabolites such as amino acids [32]. In sub-optimal nutritional conditions, inoculation did not significantly increase plant $\mathrm{NH}_{4}{ }^{+}$content. Under carbon limiting conditions, uptake of both amino acids and ammonium may be down regulated. The primary uptake of nitrogen into the root cells may be in the form of amino acids instead of $\mathrm{NO}_{3}{ }^{-}$and $\mathrm{NH}_{4}{ }^{+}$[6]. The presence of $A$. chroococcum 76A appears to synergistically enhance the expression of $L E A$ under salt stress, with higher expression levels observed in

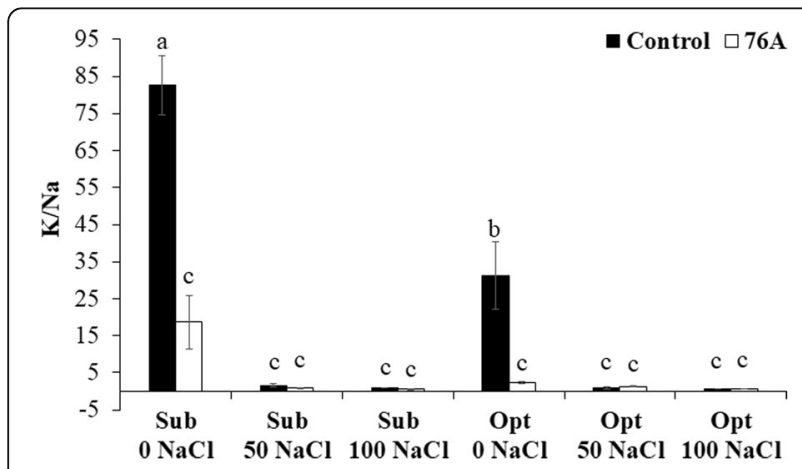

Fig. 3 Effect of Azotobacter chroococcum 76A on the leaves $\mathrm{K} / \mathrm{Na}$ ratio of Micro Tom grown under increasing salinity $(0,50,100 \mathrm{mM}$ $\mathrm{NaCl}$ ) and two nutrient regimens (Sub - Suboptimal, Opt- Optimal) inoculated plants. Interestingly, under optimal nutritional conditions, expression was elevated even in unstressed plants, with drastically higher levels of expression under salt stress conditions. Possibly the optimal nutrient solution we used, which was adapted from standard solution for soil-less production of cherry tomato plants which are larger and typically have an indeterminate growth, was not ideal for the smaller determinate MicroTom tomato in our specific experimental conditions.

The presence of $A$. chroococcum 76A appears to prime plant responses to stress. Instances of this PGPR increasing stress tolerance have been documented, but the molecular mechanisms remain unknown $[48,50,58]$. Stress priming for salt tolerance has been observed in wheat seed treated with Nitragin biofertilizer, a mixture of Azotobacter spp., Azospirillum spp. and Pseudomonas spp. Inoculation increased also germination under saline conditions [15]. Our results indicate that inoculation increases expression of at least one key gene ( $L E A)$ involved in salt and drought responses. Inoculation with $76 \mathrm{~A}$ did not appear to affect the expression of the two evaluated NHX genes (Additional file 1: Figure S1) and we observed no significant differences in $\mathrm{K}^{+}$accumulation in inoculated plants. Sodium accumulation (Fig. 2) corresponded with the expression patterns of the sodium extruder, SOS1, with lower levels of expression in sub-optimal nutrients in inoculated plants and higher levels of expression in optimal nutrients. The sodium transporter $H K T 1 ; 1$ was not significantly affected by inoculation but has been previously reported to not be highly inducible in leaves of tomato plants [52]. Inoculation with 76A appears to alter sodium transport while not affecting 

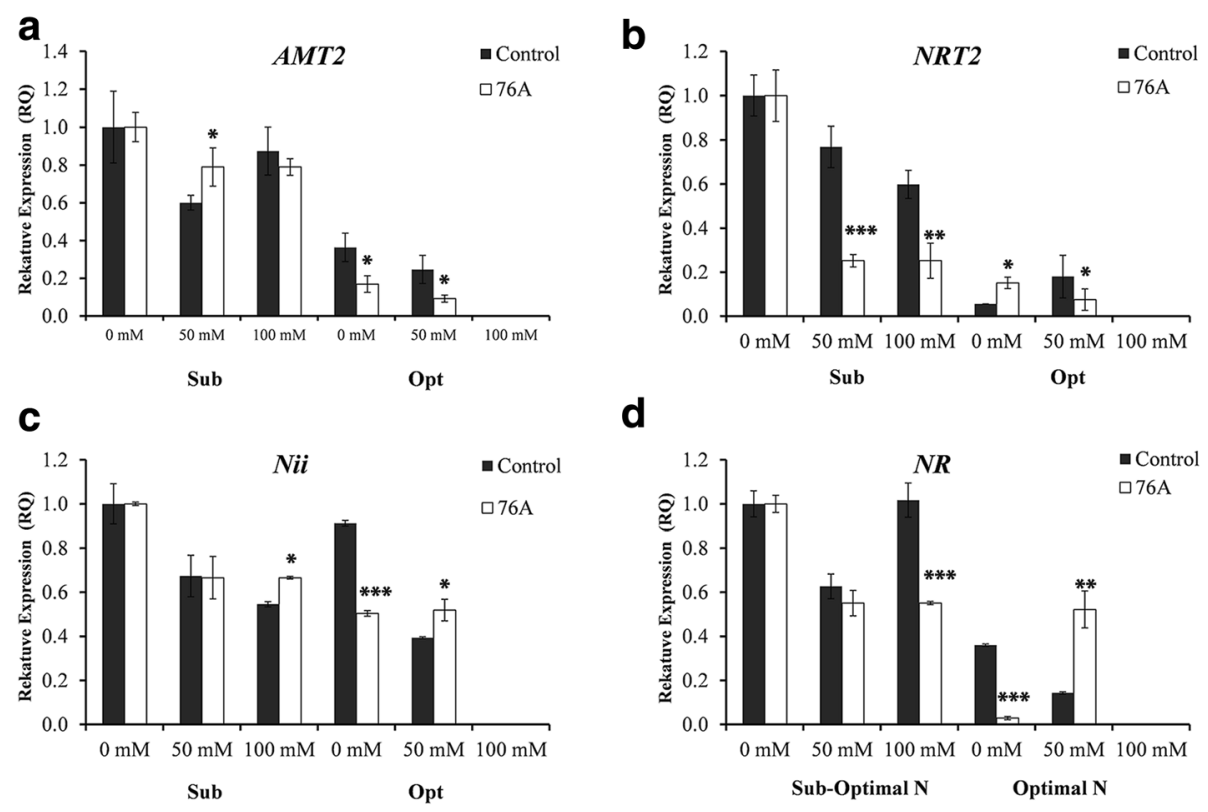

e

f
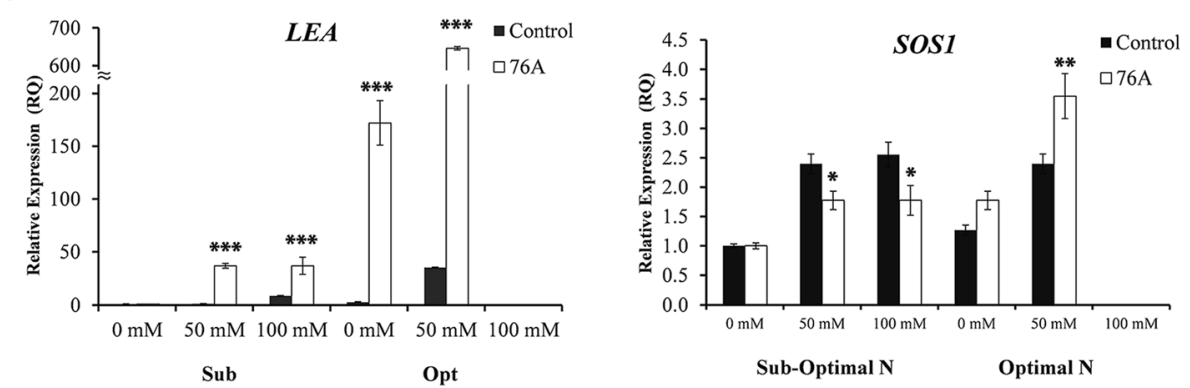

Fig. 4 Gene expression of key nitrogen assimilation enzymes and abiotic stress marker. a AMT2, (b) NRT2, (c) Nii, (d) NR, (e) LEA, (f) SOS1 relative Expression (RQ) quantified by qRT-PCR in samples of uninoculated (control) and inoculated (76A) plants treated with: $0 \mathrm{mM}, 50 \mathrm{mM}$, and $100 \mathrm{mM}$ $\mathrm{NaCl}$. Single asterisks denote significant differences according to Student $(P<0.1)$ between untreated controls and inoculated, double asterisks denote $(P<0.05)$ and triple asterisks denote $(P<0.01)$ between untreated controls and inoculated plants

potassium uptake. Overall, ion compartmentation could be one mechanism that has contributed in 76A plants to better perform under salt stress (see moderately higher $\mathrm{Na}^{+}$and $\mathrm{Cl}^{-}$associated with better growth), whereas tissue $\mathrm{Ca}^{2+}$ accumulation may have played a predominant signaling role in growth control.

\section{Conclusions}

Throughout the literature, the ability of PGPRs to enhance growth is clearly demonstrated in a number of species. It is also becoming clear that PGPRs also have the ability to enhance tolerance to both abiotic and biotic stress. In this study, we show that the $A$. chroococcum 76A strain enhances tolerance to salinity in Micro Tom tomato. We also observed stress priming in plants inoculated with A. chroococcum 76A increasing expression of key stress-related genes $(L E A)$. The application of optimal nutritional levels appears to be inhibitory to the growth promoting and stress protective effects of $A$. chroococcum 76A. Use of this PGPR may be ideal for low-input agricultural systems where large quantities of chemical fertilizer may not be readily available, portable, or affordable. A small bag of inoculum may prove far more accessible and affordable to a small-scale grower in a developing nation than nitrogen fertilizer derived from the Haber-Bosch process which requires fossil fuels. In the growing context of developing sustainable systems, using PGPRs may provide a means of increasing available nutrients to crop systems as well as increasing tolerance to abiotic stress.

\section{Additional file}

Additional file 1: Figure S1. Gene Expression of ion transporters. (A) $N H X 1$, (B) NHX2, (C) HKT1;1, relative Expression (RQ) quantified by qRTPCR in samples of uninoculated (control) and inoculated (76A) plants treated with: $0 \mathrm{mM}, 50 \mathrm{mM}$, and $100 \mathrm{mM} \mathrm{NaCl}$. Single asterisks denote 
significant differences according to Student $(P<0.1)$ between untreated controls and inoculated, double asterisks denote $(P<0.05)$ and triple asterisks denote $(P<0.01)$ between untreated controls and inoculated plants. Table S1. Primers used in this study. (DOCX $257 \mathrm{~kb}$ )

\section{Abbreviations}

76A: A. chroococcum 76A; ACC: 1-Aminocyclopropane-1-Carboxylate; AMT: $\mathrm{NH}_{4}{ }^{+}$transporter; CFU: Colony Forming Unit; DAS: Days After Sowing; DAST: Days After Stress Treatment; EC: Electrical conductivity; FDW: Fruit Dry Weight; FFW: Fruit Fresh Weight; FN: Fruit Number; I: Inoculated; LEA: Late Embryogenesis Abundant; N: Nutrition; Nii: Nitrite Reductase; NR: Nitrate Reductase; NRT: $\mathrm{NO}_{3}$ transporter; Opt: Optimal Nitrogen Nutrient Solution; RDW: Root Dry Weight; ROS: Reactive Oxygen Species; RWC: Relative Water Content; SDW: Shoot Dry Weight; SFW: Shoot Fresh Weight; SOS: Salt Overly Sensitive; SPAD: Single Photoelectric Analyzing Diode; Sub: Sub-Optimal Nitrogen Nutrient Solution; YM: Yeast Mannitol

\section{Funding}

This work was supported by the EU Projects: BIOFECTOR Plant GrowthPromoting Bio-effectors (\#FP7-KBBE-2012-6 Grant Agreement 312117) and TOMRES: A novel and integrated approach to increase multiple and combined stress tolerance in plants using tomato as a model (H2O20-EU.3.2.1.1 Grant Agreement 727929).

\section{Availability of data and materials}

The datasets used and analyzed during the current study available from the corresponding author on reasonable request.

\section{Author's contributions}

EDS, VC, SS, and MJV performed the plant growth and stress experiments and analyzed the data. $W$ and OP designed and performed the microbial experiments. GP and AM designed the project. MJV, EDS and AM wrote the manuscript. All authors have read and approved the manuscript.

\section{Ethics approval and consent to participate}

The experimental research on plants performed in this study complies with institutional, national and international guidelines.

\section{Consent for publication}

Not applicable

\section{Competing interests}

The authors declare that they have no competing interests.

\section{Publisher's Note}

Springer Nature remains neutral with regard to jurisdictional claims in published maps and institutional affiliations.

\section{Received: 9 January 2018 Accepted: 31 August 2018}

Published online: 20 September 2018

\section{References}

1. Ahmad F, Ahmad I, Khan MS. Screening of free-living rhizospheric bacteria for their multiple plant growth promoting activities. Microbiol Res. 2008;163: 173-81.

2. Anastasio M, Pepe O, Cirillo T, Palomba S, Blaiotta G, Villani F. Selection and use of phytate-degrading $L A B$ to improve cereal-based products by mineral solubilization during dough fermentation. J Food Sci. 2010;75:M28-35.

3. Batelli G, Massarelli I, Van Oosten M, Nurcato R, Vannini C, Raimondi G, et al. Asg1 is a stress-inducible gene which increases stomatal resistance in salt stressed potato. J Plant Physiol. 2012;169:1849-57.

4. Batistič O, Kudla J. Analysis of calcium signaling pathways in plants. Biochim Biophys Acta Gen Subj. 2012;1820:1283-93.

5. Cejudo FJ, Paneque A. Short-term nitrate (nitrite) inhibition of nitrogen fixation in Azotobacter chroococcum. J Bacteriol. 1986;165:240-3.

6. Chalot M, Blaudez D, Brun A. Ammonia: a candidate for nitrogen transfer at the mycorrhizal interface. Trends Plant Sci. 2006;11:263-6.

7. Chaudhary D, Narula N, Sindhu SS, Behl RK. Plant growth stimulation of wheat (Triticum aestivum L.) by inoculation of salinity tolerant Azotobacter strains. Physiol Mol Biol Plants. 2013;19:515-9.
8. Chinnusamy V, Schumaker K, Zhu J-K. Molecular genetic perspectives on cross-talk and specificity in abiotic stress signalling in plants. J Exp Bot. 2004 55:225-36.

9. Cubero B, Nakagawa $Y$, Jiang $X-Y$, Miura K-J, Li F, Raghothama KG, et al. The phosphate transporter PHT4;6 is a determinant of salt tolerance that is localized to the Golgi apparatus of Arabidopsis. Mol Plant. 2009;2:535-52.

10. Debouba M, Dguimi HM, Ghorbel M, Gouia H, Suzuki A. Expression pattern of genes encoding nitrate and ammonium assimilating enzymes in Arabidopsis thaliana exposed to short term NaCl stress. J Plant Physiol. 2013;170:155-60.

11. De Pascale S, Martino A, Raimondi G, Maggio A. Comparative analysis of water and salt stress-induced modifications of quality parameters in cherry tomatoes. J Hortic Sci Biotechnol. 2007;82:283-9.

12. De Pascale S, Orsini F, Caputo R, Palermo MA, Barbieri G, Maggio A. Seasonal and multiannual effects of salinisation on tomato yield and fruit quality. Functional Plant Biol. 2012;39:689-98.

13. De Pascale SD, Costa LD, Vallone S, Barbieri G, Maggio A. Increasing water use efficiency in vegetable crop production: from plant to irrigation systems efficiency. HortTechnology. 2011;21:301-8.

14. El-Shanshoury AR, Hassan MA, Abdel-Ghaffar BA. Synergistic effect of vesicular-arbuscular mycorrhizas and Azotobacter chroococcum on the growth and the nutrient contents of tomato plants. Phyton: annales rei botanicae. 1989 [cited 2017 May 8]; Available from: http://agris.fao.org/agrissearch/search.do?recordID=US201302711501

15. Fallahi J, Moghaddam PR, Mahallati MN, Behdani MA, Shajari MA, Amiri MB. Influence of seed nitrogen content and biofertilizer priming on wheat germination in salinity stress conditions. Arch Agron Soil Sci. 2013;59:791-801.

16. Flowers TJ, Munns R, Colmer TD. Sodium chloride toxicity and the cellular basis of salt tolerance in halophytes. Ann Bot. 2015;115:419-31.

17. Hasegawa PM. Sodium ( $\mathrm{Na}+$ ) homeostasis and salt tolerance of plants. Environ Exp Bot. 2013:92:19-31.

18. Hayat S, Hasan SA, Fariduddin Q, Ahmad A. Growth of tomato (Lycopersicon esculentum) in response to salicylic acid under water stress. J Plant Interact. 2008;3:297-304

19. Iovieno P, Punzo P, Guida G, Mistretta C, Van Oosten MJ, Nurcato R, et al. Transcriptomic Changes Drive Physiological Responses to Progressive Drought Stress and Rehydration in Tomato. Front Plant Sci [Internet]. 2016 [cited 2017 May 15];7. Available from: http://www.ncbi.nlm.nih.gov/pmc/ articles/PMC4814702/

20. Jeppesen E, Brucet S, Naselli-Flores L, Papastergiadou E, Stefanidis K, Nõges $T$, et al. Ecological impacts of global warming and water abstraction on lakes and reservoirs due to changes in water level and related changes in salinity. Hydrobiologia. 2015;750:201-27.

21. Ji H, Pardo JM, Batelli G, Van Oosten MJ, Bressan RA, Li X. The salt Overly sensitive (SOS) pathway: established and emerging roles. Mol Plant. 2013;6:275-86.

22. Jones MM, Turner NC. Osmotic adjustment in leaves of Sorghum in response to water deficits. Plant Physiol. 1978;61:122-6.

23. Joseph B, Ranjan Patra R, Lawrence R. Characterization of plant growth promoting rhizobacteria associated with chickpea (Cicer arietinum L.). International Journal of Plant Production. 2012:1:141-52.

24. Khalilzadeh R, Sharifi RS, Jalilian J. Antioxidant status and physiological responses of wheat (Triticum aestivum L.) to cycocel application and bio fertilizers under water limitation condition. J Plant Interact. 2016;11:130-7.

25. Kilam D, Saifi M, Abdin MZ, Agnihotri A, Varma A. Combined effects of Piriformospora indica and Azotobacter chroococcum enhance plant growth, antioxidant potential and steviol glycoside content in Stevia rebaudiana. Symbiosis. 2015;66:149-56

26. Kumar $\mathrm{P}$, Rouphael $Y$, Cardarelli M, Colla G. Effect of nickel and grafting combination on yield, fruit quality, antioxidative enzyme activities, lipid peroxidation, and mineral composition of tomato. J Plant Nutr Soil Sci. 2015;178:848-60.

27. Kumar V, Kumar Behl R, Narula N. Establishment of phosphate-solubilizing strains of Azotobacter chroococcum in the rhizosphere and their effect on wheat cultivars under green house conditions. Microbiol Res. 2001;156:87-93.

28. Kaushal M, Wani SP. Plant-growth-promoting rhizobacteria: drought stress alleviators to ameliorate crop production in drylands. Ann Microbiol. 2016; 66:35-42.

29. Larbat R, Paris C, Le Bot J, Adamowicz S. Phenolic characterization and variability in leaves, stems and roots of micro-tom and patio tomatoes, in response to nitrogen limitation. Plant Sci. 2014;224:62-73.

30. Maggio A, Zhu J-K, Hasegawa PM, Bressan RA. Osmogenetics: Aristotle to Arabidopsis. Plant Cell. 2006;18:1542-57. 
31. Markwell J, Osterman JC, Mitchell JL. Calibration of the Minolta SPAD-502 leaf chlorophyll meter. Photosynth Res. 1995;46:467-72.

32. Masclaux-Daubresse C, Daniel-Vedele F, Dechorgnat J, Chardon F, Gaufichon $L$, Suzuki A. Nitrogen uptake, assimilation and remobilization in plants: challenges for sustainable and productive agriculture. Ann Bot. 2010;105: 1141-57.

33. Mayak S, Tirosh T, Glick BR. Plant growth-promoting bacteria confer resistance in tomato plants to salt stress. Plant Physiol Biochem. 2004;42: 565-72.

34. Mickelbart MV, Hasegawa PM, Bailey-Serres J. Genetic mechanisms of abiotic stress tolerance that translate to crop yield stability. Nat Rev Genet. 2015;16: 237-51.

35. Munns R, Tester M. Mechanisms of salinity tolerance. Annu Rev Plant Biol. 2008;59:651-81.

36. Narayan RP, Kehri HK. Effect of different agricultural practices on population dynamics of Azotobacter chroococcum and on its nitrogen fixing potentiality in trans-ganga and trans-Yamuna plains of India. Acta Agriculturae Serbica. 2011;16:97-122.

37. Olías R, Eljakaoui Z, Li J, Morales PAD, Marín-Manzano MC, Pardo JM, et al. The plasma membrane $\mathrm{Na}+/ \mathrm{H}+$ antiporter SOS1 is essential for salt tolerance in tomato and affects the partitioning of $\mathrm{Na}+$ between plant organs. Plant Cell Environment. 32:904-16.

38. Ordookhani K, Moezi A, Khavazi K, Rejali F. Effect of plant growth promoting rhizobacteria and mycorrhiza on tomato fruit quality. Acta Hortic. 2013:91-6.

39. Panta S, Flowers T, Lane P, Doyle R, Haros G, Shabala S. Halophyte agriculture: success stories. Environ Exp Bot. 2014;107:71-83.

40. Pepe $O$, Ventorino $V$, Blaiotta $G$. Dynamic of functional microbial groups during mesophilic composting of agro-industrial wastes and free-living (N2)-fixing bacteria application. Waste Manag. 2013;33:1616-25.

41. Reich M, Aghajanzadeh T, Helm J, Parmar S, Hawkesford MJ, Kok LJD. Chloride and sulfate salinity differently affect biomass, mineral nutrient composition and expression of sulfate transport and assimilation genes in Brassica rapa. Plant Soil. 2017;411:319-32.

42. Rojas-Tapias D, Moreno-Galván A, Pardo-Díaz S, Obando M, Rivera D, Bonilla R. Effect of inoculation with plant growth-promoting bacteria (PGPB) on amelioration of saline stress in maize (Zea mays). Appl Soil Ecol. 2012;61: 264-72.

43. Rozema J, Flowers T. Ecology: crops for a salinized world. Science. 2008;322: 1478-80.

44. Serrani JC, Fos M, Atarés A, García-Martínez JL. Effect of gibberellin and auxin on Parthenocarpic fruit growth induction in the cv micro-tom of tomato. J Plant Growth Regul. 2007;26:211-21.

45. Shaharoona B, Arshad M, Zahir ZA, Khalid A. Performance of Pseudomonas spp. containing ACC-deaminase for improving growth and yield of maize (Zea mays L.) in the presence of nitrogenous fertilizer. Soil Biol Biochem. 2006:38:2971-5.

46. Sharifi RS, Khalilzadeh R, Jalilian J. Effects of biofertilizers and cycocel on some physiological and biochemical traits of wheat (Triticum aestivum L.) under salinity stress. Arch Agron Soil Sci 2016;0:1-11.

47. Sharma S, Thakur K. Effect of Azotobacter and nitrogen on plant growth and fruit yield of tomato. Veg Sci. 2001;28:146-8.

48. Singh NB, Singh D, Singh A. Biological seed priming mitigates the effects of water stress in sunflower seedlings. Physiol Mol Biol Plants. 2015;21:207-14.

49. Singh NK, Chaudhary FK, Patel DB. Effectiveness of Azotobacter bioinoculant for wheat grown under dryland condition. J Environ Biol. 2013;34: 927-32.

50. Štajner D, Kevrešan S, Gašić O, Mimica-Dukić N, Zongli H. Nitrogen and Azotobacter chroococcum enhance oxidative stress tolerance in sugar beet. Biol Plant. 1997;39:441.

51. Swarnalakshmi K, Prasanna R, Kumar A, Pattnaik S, Chakravarty K, Shivay YS, et al. Evaluating the influence of novel cyanobacterial biofilmed biofertilizers on soil fertility and plant nutrition in wheat. Eur J Soil Biol. 2013;55:107-16.

52. Van Oosten MJ, Silletti S, Guida G, Cirillo V, Di Stasio E, Carillo P, et al. A Benzimidazole Proton Pump Inhibitor Increases Growth and Tolerance to Salt Stress in Tomato. Front Plant Sci [Internet]. 2017a [cited 2018 May 29];8. Available from: https://www.frontiersin.org/articles/10.3389/fpls.2017.01220/full

53. Van Oosten MJ, Pepe O, Pascale S, Silletti S, Maggio A. The role of biostimulants and bioeffectors as alleviators of abiotic stress in crop plants. Chemical and Biological Technologies in Agriculture. 2017b;4:5.

54. Viscardi S, Ventorino V, Duran P, Maggio A, De Pascale S, Mora ML, et al. Assessment of plant growth promoting activities and abiotic stress tolerance of Azotobacter chroococcum strains for a potential use in sustainable agriculture. J Soil Sci Plant Nutr. 2016;16:848-63.

55. Wani SA, Chand S, Wani MA, Ramzan M, Hakeem KR. Azotobacter chroococcum - A Potential Biofertilizer in Agriculture: An Overview. In: Hakeem KR, Akhtar J, Sabir M, editors. Soil Science: Agricultural and Environmental Prospectives [Internet]. Springer International Publishing; 2016 [cited 2017 Feb 23]. p. 333-48. Available from: http://link.springer.com/ chapter/10.1007/978-3-319-34451-5_15

56. White PJ, Broadley MR. Calcium in plants. Ann Bot. 2003;92:487-511.

57. Yadav S, Irfan M, Ahmad A, Hayat S., 2011. Causes of salinity and plant manifestations to salt stress: a review. J Environ Biol. 32(5):667-85.

58. Yousefi S, Kartoolinejad D, Bahmani M, Naghdi R. Effect of Azospirillum lipoferum and Azotobacter chroococcum on germination and early growth of hopbush shrub (Dodonaea viscosa L.) under salinity stress. J Sustain For 2016;0:1-14
Ready to submit your research? Choose BMC and benefit from:

- fast, convenient online submission

- thorough peer review by experienced researchers in your field

- rapid publication on acceptance

- support for research data, including large and complex data types

- gold Open Access which fosters wider collaboration and increased citations

- maximum visibility for your research: over $100 \mathrm{M}$ website views per year

At BMC, research is always in progress.

Learn more biomedcentral.com/submissions 